\title{
Detection of Entamoeba histolytica DNA in the Saliva of Amoebic Liver Abscess Patients Who Received Prior Treatment with Metronidazole
}

\author{
Krishna Khairnar and Subhash Chandra Parija \\ Department of Microbiology, Jawaharlal Institute of Postgraduate Medical Education and \\ Research, Puducherry 605 006, India
}

\begin{abstract}
Saliva is an easily-accessible and a non-invasive clinical specimen alternate to blood and liver pus. An attempt was made to detect Entamoeba histolytica DNA released in the saliva of amoebic liver abscess (ALA) patients by applying 16S-like rRNA gene-based nested multiplex polymerase chain reaction (NM-PCR). The NM-PCR detected $E$. histolytica DNA in the saliva of eight (28.6\%) of 28 ALA patients. The NM-PCR result was negative for $E$. histolytica DNA in the saliva of all the eight ALA patients who were tested prior to treatment with metronidazole but was positive in the saliva of eight (40\%) of 20 ALA patient who were tested after therapy with metronidazole. The NM-PCR detected $E$. histolytica DNA in liver abscess pus of all 28 (100\%) patients with ALA. The TechLab E. histolytica II enzyme-linked immunosorbent assay was positive for $E$. histolytica Gal/GalNAc lectin antigen in the liver abscess pus of $13(46.4 \%)$ of the 28 ALA patients. The indirect haemagglutination (IHA) test was positive for anti-amoebic antibodies in the serum of 22 (78.6\%) of the 28 ALA patients and 2 (5.7\%) of 35 healthy controls. The present study, for the first time, demonstrates the release of $E$. histolytica DNA in the saliva of ALA patients by applying NM-PCR.
\end{abstract}

Key words: Amoebiasis; DNA; Entamoeba histolytica; Metronidazole; Polymerase chain reaction; Saliva; India

\section{INTRODUCTION}

The use of saliva as a diagnostic fluid has been increasingly reported worldwide in the last decade. Technological advancement has taken place during the past few years enabling the use of saliva as a clinical specimen to diagnose disease and predict disease progression (1).

Initially, saliva was used as a clinical specimen for antibody detection in the diagnosis of infectious diseases. Detection of salivary antibody was found to be useful for the diagnosis of bacterial infections caused by Helicobacter pylori, Shigella, and Borrelia burgdorferi (2-4) and various viral infections, such as hepatitis A, hepatitis B, hepatitis C, measles,

Correspondence and reprint requests should be addressed to:

Dr. Subhash Chandra Parija

Director-Professor and Head

Department of Microbiology

Jawaharlal Institute of Postgraduate

Medical Education and Research

Puducherry 605006

India

Email: parijasc@vsnl.com

Fax: 91-413-2272067 mumps, rubella, rotavirus, dengue, parvovirus B 19, and HIV (5-11). Detection of salivary antibody has also been studied for the diagnosis of some parasitic infections caused by Toxoplasma gondii, Schistosoma mansoni, Taenia solium, and Entamoeba histolytica (12-15).

Subsequently, saliva has also been used for the detection of antigen in the diagnosis of pneumococcal pneumonia (16), hepatitis B virus, measles, mumps, and rubella (17-20). There is only one report till date on the detection of salivary lectin antigen of $E$. histolytica for the diagnosis of amoebic liver abscess (ALA) with a sensitivity and specificity of $22 \%$ and $97.4 \%$ respectively (21).

The reports on the use of saliva for the detection of DNA for the diagnosis of infectious diseases, however, are limited (22-26). The polymerase chain reaction (PCR) has been used for facilitating diagnosis of viral infections, such as Epstein-Barr, cytomegalovirus, human herpes virus 6,7 , and 8 , and rabies using saliva (22-25). The PCR has also been evaluated for the detection of $H$. pylori-associated peptic ulcer, by demonstration of $H$. pylori DNA in saliva (26). However, reports on the detection of DNA 
in saliva of patients with parasitic infection, even amoebiasis, is still lacking. In the present study, we, therefore, made an attempt to detect $E$. histolytica DNA, possibly released in the saliva of ALA patients by applying a 16S-like rRNA gene-based nested multiplex PCR (NM-PCR) assay. ALA is a condition which is the most important and serious extra-intestinal manifestation of amoebiasis, which is associated with high morbidity and mortality. An early and specific diagnosis of the condition followed by immediate treatment reduces morbidity and mortality due to the disease to a great extent.

\section{MATERIALS AND METHODS}

\section{Sample details}

The present study was conducted in the Jawaharlal Institute of Postgraduate Medical Education and Research (JIPMER) Hospital, Puducherry, India, during August 2005-March 2006.

Patients with ALA $(n=28)$ : The study included 28 ALA patients; diagnosis was done on the basis of radiological, symptomatological and laboratory criteria $(27,28)$, such as: (a) ultrasonography revealing a space-occupying lesion in the liver suggestive of an abscess; (b) clinical symptoms, such as pain in the right hypochondrium, lower chest, back, or tip of the right shoulder, and fever; (c) distended and/or tender liver, generally without jaundice; (d) chest radiograph showing raised right dome of the diaphragm; (e) treatment with anti-amoebic drugs, e.g. metronidazole, results in improvement of the condition; (f) positive indirect haemagglutination (IHA) of serum antibody showing a titre $(\geq 1: 128)$ against $E$. histolytica; and (g) liver aspirate appeared like anchovy sauce but was bacteriologically sterile.

In the present study, the 28 ALA patients included eight patients on whom the metronidazole therapy was not initiated and 20 patients on whom the metronidazole therapy was already initiated.

Patients with pyogenic liver abscess (PLA) and other diseases of the liver $(n=21)$ : The study included cases of PLA $(n=13)$, hydatid cyst in liver $(n=2)$, liver hepatoma $(n=1)$, liver cirrhosis $(n=3)$, and viral hepatitis $(\mathrm{n}=2)$.

Healthy control $(\mathbf{n}=35)$ : The study included 35 healthy controls who had no history of recent dysentery or diarrhoea and whose stool samples were negative for E. histolytica-associated infection by microscopy and culture.

\section{Sample collection}

Saliva: Saliva specimens were collected from all the 28 ALA patients, 21 patients with PLA and other diseases of the liver, and 35 healthy controls. $5 \mathrm{~mL}$ of saliva specimen was collected from each individual in a sterile container using the aseptic techniques and was stored at $4{ }^{\circ} \mathrm{C}$ until used.

Liver abscess pus: The aspiration of liver abscess pus was indicated only under the following conditions (27): (a) to rule out a pyogenic abscess; (b) the failure to respond clinically in 3-5 days; (c) the threat of imminent rupture; and (d) the prevention of rupture of left-lobe abscess into the pericardium. The liver abscess pus aspirates were performed, only for clinical purposes as judged by the clinicians for the patient care and not for the purpose of this study. Liver abscess pus was obtained under ultrasound guidance from all the 28 ALA patients and 13 PLA patients and was stored at $-20^{\circ} \mathrm{C}$ in a sterile container until used.

Blood: Blood specimens were collected from all the 28 ALA patients, 21 with PLA and other diseases of the liver, and 35 healthy controls. $5 \mathrm{~mL}$ of venous blood was collected in a sterile container; sera were separated and stored at $-20^{\circ} \mathrm{C}$ until used.

\section{Detection of anti-amoebic antibodies in serum by IHA}

The Rapid-IHA was performed on serum specimen as per the method described earlier (29). A titre of $\geq 1: 128$ was considered to be positive for ALA (30).

Detection of Gal/GalNAc lectin antigen in liver pus by TechLab E. histolytica II ELISA

The TechLab E. histolytica II test was performed on liver abscess pus specimens to detect $E$. histolyticaspecific Gal/GalNAc lectin antigen as per the method described earlier (28).

\section{NM-PCR}

\section{Extraction of Entamoeba genomic DNA from saliva and liver abscess pus}

The protocol for extraction of DNA from saliva and liver abscess pus specimen has been modified in our laboratory from cetyltrimethylammonium bromide (CTAB) DNA extraction protocol originally described for DNA extraction from amoebic culture (31).

Saliva: Briefly, $5 \mathrm{~mL}$ of saliva was centrifuged at $12,000 \mathrm{~g}$ for eight minutes at $4{ }^{\circ} \mathrm{C}$. The supernatant 
was discarded, and the pellet was suspended in 250 $\mu \mathrm{L}$ of sterile distilled water. To the suspension $5 \mu \mathrm{L}$ of proteinase-K $(10 \mathrm{mg} / \mathrm{mL})$ and $40 \mu \mathrm{L}$ of $10 \%$ sodium dodecyl sulphate was added and incubated for three hours at $65{ }^{\circ} \mathrm{C}$. Then, $60 \mu \mathrm{L}$ of $5 \mathrm{M}$ sodium chloride and $15 \mu \mathrm{L}$ of $10 \% \mathrm{CTAB}$ were added to the mixture and incubated for 45 minutes at $65^{\circ} \mathrm{C}$. This was followed by extractions with equal volumes of chloroform and then phenol-chloroform-isoamyl alcohol. The DNA was precipitated with ice-cold ethanol. The dried DNA pellet was dissolved in 50 $\mu \mathrm{L}$ of sterile distilled water.

Liver abscess pus: The extraction of Entamoeba genomic DNA from liver abscess pus was performed as per the method described earlier (32).

The extracted DNA from saliva and liver abscess pus sample was passed through DNA clean-up spin columns (Bangalore Genei KT-62, Bangalore). The DNA was stored at $-20{ }^{\circ} \mathrm{C}$ until used.

\section{Quantification of DNA in saliva and liver abscess pus}

DNA quantification in spin column-purified DNA extract from saliva and liver abscess pus specimens was determined by ultraviolet (UV) absorbance using a Cintra 5 double beam spectrophotometer. DNA yield was calculated on the basis of UV absorbance $x$ dilution. The purity of the nucleic acid in the samples was estimated by the ratio of readings at $260 \mathrm{~nm}$ and $280 \mathrm{~nm}\left(\mathrm{OD}_{260} / \mathrm{OD}_{280}\right)$.

\section{Primers used}

Based on the sequences of the 16S-like rRNA gene of E. histolytica, E. dispar, and E. moshkovskii nested set of primers (designated E-1/E-2, EH-1/EH-2, ED-1/ ED-2, and Mos-1/Mos-2) were used as previously described (32).

In addition, we have used an internal amplification control (IAC) targeting human 18S ribosomal RNA gene to rule out false-negative results in clinical specimens as previously described (32).

\section{Primer validation}

The primer sequences for E. moshkovskii, E. histolyti$c a, E$. dispar, and human IAC were subjected to the basic local alignment search tool (BLAST) in the genome database of all organisms available at http:// www.ncbi.nlm.nih.gov/blast/ and were found to be specific for the study. The $439 \mathrm{bp}$ PCR products of $E$. histolytica species from representative saliva and liver abscess pus specimens were confirmed by getting both the strands of DNA sequenced on ABI3730XL sequencer (Macrogen, Seoul, South Korea). The nucleotide sequencing was done using species-specific primers, i.e. EH-1/EH-2, for E. histolytica. The nucleotide sequences were analyzed for homology using the nucleotide-nucleotide BLAST search feature available at http://www.ncbi.nlm. nih.gov/blast/. The identities between the nucleotide sequencing result of representative $439 \mathrm{bp}$ PCR products of $E$. histolytica species from saliva and liver abscess pus specimens with the sequence deposited in GenBank [accession number: X56991] were analyzed using 'Align two sequences (bl2seq)' feature available at http://www.ncbi.nlm.nih.gov/blast/. The multiple sequence alignment of the nucleotide sequences of representative $439 \mathrm{bp}$ PCR products of E. histolytica species from saliva and liver abscess pus specimens with the sequence deposited in GenBank [accession number: X56991] was also done using the BioEdit software (version 7).

\section{Standard strains}

Three standard strains-E. histolytica HM-1:IMSS, E. dispar SAW760, and E. moshkovskii Laredo-were used as positive control in the present study. The lyophilized DNA of these strains was generously gifted by Dr. C. Graham Clark from the London School of Hygiene \& Tropical Medicine, UK.

\section{NM-PCR for saliva and liver abscess pus}

Saliva PCR: For a reaction volume of $25 \mu \mathrm{L}$, comprising $2.5 \mu \mathrm{L}$ of 10X PCR buffer (Biogene, Kimbolton, UK), $1.0 \mu \mathrm{L}$ of $25 \mathrm{mM} \mathrm{MgCl}_{2}$ (Bangalore Genei, Bangalore, India), $0.75 \mu \mathrm{L}$ of deoxy-ribonucleotide triphosphate mix (10 mM each dNTP, Biogene, Kimbolton, UK), $0.3 \mu \mathrm{L}(5 \mathrm{IU} / \mu \mathrm{L})$ of Taq polymerase (Biogene, Kimbolton, UK), 10 picomoles of target DNA primers (IDT, Coralville, USA), and 5 picomoles of IAC primers (IDT, Coralville, USA) were added in genus- and species-specific PCR. The template DNA volume was $2 \mu \mathrm{L}$ for both genus- and species-specific PCR. The PCR tubes were finally placed in an Eppendorf thermal cycler (master cycler gradient; Westbury, NY, USA).

The conditions for genus-specific PCR were as follows; the PCR mix was subjected to an initial denaturation at $96{ }^{\circ} \mathrm{C}$ for two minutes, followed by 30 cycles - each consisting of $92^{\circ} \mathrm{C}$ for 60 seconds (denaturation), $56^{\circ} \mathrm{C}$ for 60 seconds (annealing), and $72^{\circ} \mathrm{C}$ for 90 seconds (extension). Finally, one cycle of extension at $72{ }^{\circ} \mathrm{C}$ for seven minutes was performed. In the species-specific NM-PCR (which had multiple primer-sets in the same tube), only 
the annealing temperature was changed to $48{ }^{\circ} \mathrm{C}$, leaving the other parameters of the amplification cycles unchanged.

Liver abscess pus PCR: The PCR mix composition and PCR conditions for the amplification of Entamoeba 16S-like rRNA gene from liver abscess pus was performed as per the method described earlier (32).

$3.5 \mu \mathrm{L}$ of the amplification product was separated by electrophoresis through $1.8 \%$ agarose gel (Agarose Low EEO; Bangalore Genie, Bangalore, India) containing ethidium bromide in $0.5 \mathrm{X}$ Tris-borateEDTA at $120 \mathrm{~V}$ for 45 minutes and was visualized under UV light for bands of DNA of appropriate sizes (Fig.).

\section{Analysis of statistical data}

Sensitivity was calculated as the number of patients with positive test results/total number of patients $\times 100$. Specificity was calculated as the number of controls with negative test results divided by total number of controls $\times 100$. To calculate the significance of the difference in sensitivities, McNemar's chi-square test was applied. The McNemar's test was performed using the Graph Pad Software.

Fig. Results of nested multiplex PCR on representative saliva and liver abscess pus specimen

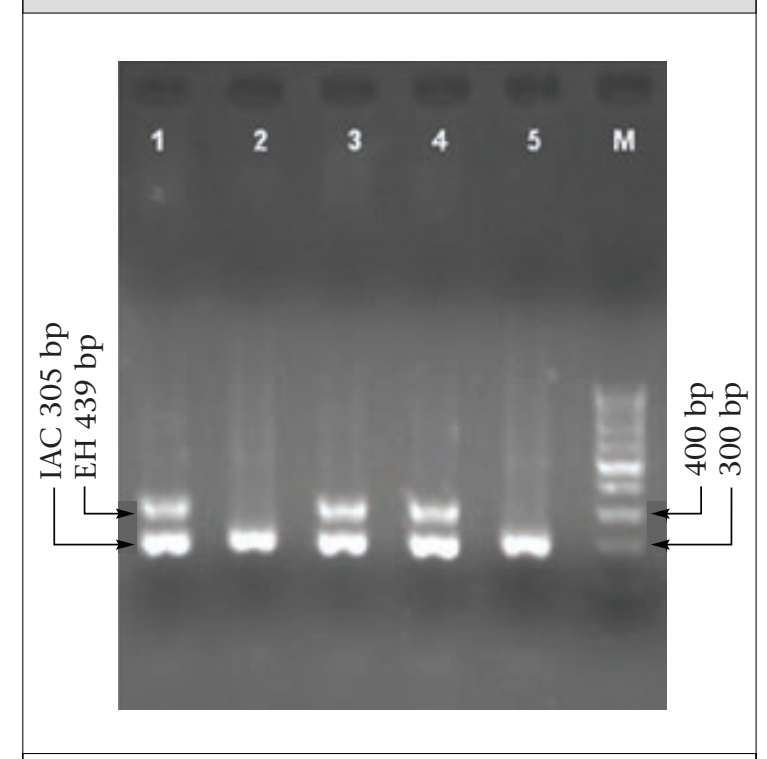

The E. histolytica (EH) and internal amplification control (IAC) bands are 439 and 305 bp respectively. Lane 1 is positive for E. histolytica DNA in saliva; Lane 3 and 4 are positive for E. histolytica DNA in liver abscess pus; Lane 2 and 5 are negative for E. histolytica DNA; Lane M, 100 bp DNA ladder (Bangalore Genei, Bangalore)

\section{RESULTS}

\section{Detection of anti-amoebic antibodies in serum by IHA}

The IHA test was positive for anti-amoebic antibodies in the serum of $22(78.6 \%)$ of the 28 ALA patients and two (5.7\%) of 35 healthy controls. The IHA test was negative for anti-amoebic antibodies in the serum of all 21 patients with PLA and other diseases of the liver.

Detection of Gal/GalNAc lectin antigen in liver pus by TechLab

\section{E. histolytica II ELISA}

The TechLab E. histolytica II enzyme-linked immunosorbent assay (ELISA) test was positive for $E$. histolytica Gal/GalNAc lectin antigen in the liver abscess pus of 13 (46.4\%) of the 28 ALA patients. The TechLab E. histolytica II ELISA detected E. histolytica lectin antigen in the liver pus of all the eight (100\%) ALA patients who were tested prior to treatment with metronidazole but was detected in only five (25\%) of the 20 ALA patients who were tested after the initiation of therapy with metronidazole. This might be due to the rapid clearing of amoebic antigen from the liver pus due to killing of E. histolytica trophozoites on treatment with metronidazole. The TechLab E. histolytica II ELISA test was negative for E. histolytica Gal/GalNAc lectin antigen in the liver abscess pus of all the 13 patients with PLA.

\section{NM-PCR}

\section{Quantification of DNA in saliva and liver abscess pus}

The average DNA yield for all saliva and liver abscess pus specimens was found to be approximately 33 and $85 \mu \mathrm{g} / \mathrm{mL}$ respectively by spectrophotometric analysis. The purity of DNA extract from saliva and liver abscess pus specimens was found to be satisfactory as the ratio of readings at $260 \mathrm{~nm}$ and $280 \mathrm{~nm}\left(\mathrm{OD}_{260} / \mathrm{OD}_{280}\right)$ was approximately 1.8 .

\section{Primer validation}

The sequencing result of representative 439 bp PCR products of $E$. histolytica species from saliva and liver abscess pus specimens showed $99-100 \%$ identities to the sequence deposited in GenBank [accession number: X56991]. The multiple sequence alignment of the nucleotide sequences of representative 439 bp PCR products of $E$. histolytica species from saliva and liver abscess pus specimens with the sequence deposited in GenBank [accession number: X56991] showed no discrepancy. 


\section{NM-PCR for saliva and liver abscess pus}

The NM-PCR performed on the representative sadetected E. histolytica DNA in eight (28.6\%) of the 28 saliva specimens collected from the ALA patients (Table). The NM-PCR was negative for E. histolytica DNA in the saliva of all the eight ALA patients who were tested prior to treatment with metronidazole but was positive in the saliva of eight (40\%) of the 20 ALA patients who were tested after therapy with metronidazole. The NM-PCR was negative for with PLA and other diseases of the liver and 35 healthy controls (Table). In this study, the probability of negative NM-PCR results in the saliva specimens due to PCR inhibitors was ruled out by the inclusion of an IAC in the PCR reaction.

The result of NM-PCR performed on the liver abscess pus is depicted in the figure. The NM-PCR was positive for $E$. histolytica DNA in all the 28 liver abscess pus specimens (100\%) from the ALA patients (Table). The test did not detect $E$. histolytica DNA in liver abscess pus from all the 13 patients with PLA.

\section{DISCUSSION}

It is difficult to differentiate clinically the ALA from PLA and from other space-occupying lesions of the liver, such as hydatid cyst and liver hepatoma $(27,33)$. Although the imaging techniques are highly sensitive to detect abscesses in the liver of varied aetiology, these fail to distinguish specifically ALA from that of PLA.

The demonstration of E. histolytica trophozoite in the liver pus by microscopy confirms the diagnosis of ALA, but in best of the conditions, the amoebic trophozoites can be demonstrated in only $15 \%$ of liver pus (34). Therefore, the laboratory diagnosis of ALA is usually established by antibody-based serological tests, but the serum antibody levels in individuals living in endemic areas continue to remain positive even for years after eradication of infection with E. histolytica (35-37). A monoclonal antibody-based second-generation TechLab E. histolytica II ELISA has been reported to be $78 \%$ and $40.7 \%$ sensitive for the detection of $E$. histolytica Gal/GalNAc lectin antigen in the serum and liver pus of ALA patients respectively (28).

Earlier, the PCR to detect Entamoeba DNA in stool samples has been evaluated as a sensitive and specific method for the diagnosis of intestinal amoebiasis (38-46). Studies conducted in various laboratories worldwide have shown that PCR has a varied liva specimen is shown in the figure. The NM-PCR E. histolytica DNA in the saliva of all the 21 patients

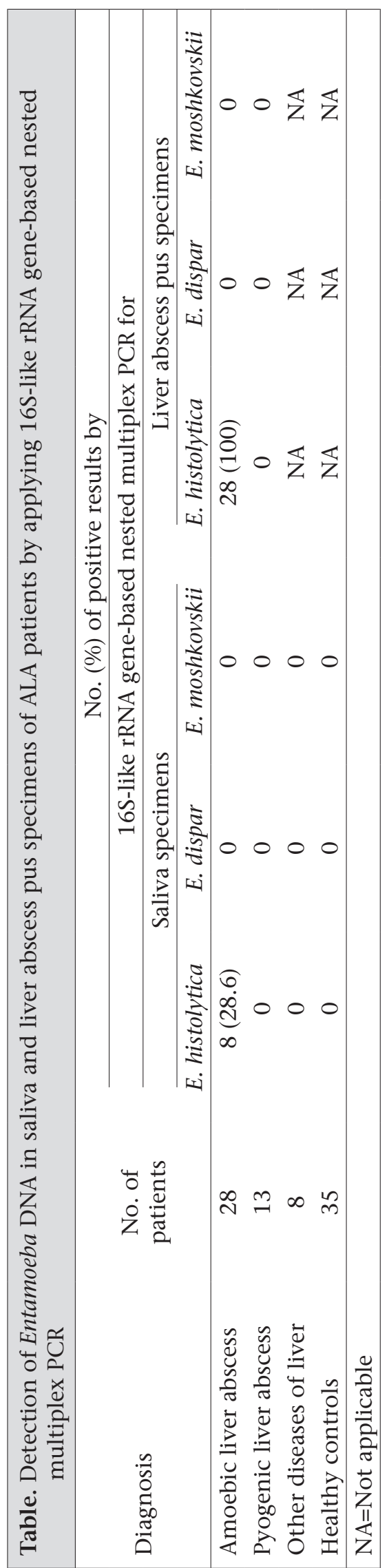

422 
sensitivity ranging from 33\% to 100\% for detecting E. histolytica DNA in liver abscess pus for the diagnosis of ALA (28,32,47-49). Recently, we have reported, for the first time, the excretion of $E$. histolytica DNA in the urine of ALA patients by applying PCR (32).

Like urine, saliva is also an easily-accessible and non-invasive body-fluid. Detection of salivary antigen has been studied earlier for the diagnosis of a few viral infections, such as Epstein-Barr virus and hepatitis B virus $(17,50)$. There is only one report on the detection of $E$. histolytica Gal/GalNAc lectin antigen in the saliva of ALA patients (21). Although reports are available for the detection of salivary DNA by PCR for the diagnosis of Epstein-Barr virus, cytomegalovirus, human herpes virus 6, 7, and 8, rabies virus, and $H$. pylori (22-26), till now, to the best of our knowledge, there is no report available on the detection of E. histolytica DNA in saliva.

In the present study, an attempt was made, for the first time, to detect Entamoeba DNA in saliva of ALA patients by applying NM-PCR. The NM-PCR in the study detected $E$. histolytica DNA in eight (28.6\%) of the 28 saliva specimens collected from the ALA patients (Table). The assay detected E. histolytica DNA in saliva of eight of the 20 cases with ALA, who were already treated with metronidazole. The PCR did not detect E. histolytica DNA in saliva of the remaining eight cases of ALA, who were not treated with metronidazole. This might be due to the release of $E$. histolytica DNA from the dying E. histolytica trophozoites when metronidazole therapy was initiated, which might have led to the release of $E$. histolytica DNA in the saliva of ALA patients.

The sensitivity of NM-PCR to detect E. histolytica DNA in the saliva was $28.6 \%$. This was found to be significantly lower than the sensitivity of NMPCR to detect E. histolytica DNA in the liver abscess pus (100\%), using McNemar's chi-square test $(\mathrm{p}<0.0001)$.

The NM-PCR was negative for E. histolytica DNA in the saliva of all the 21 patients with PLA and other diseases of the liver, and 35 healthy controls. This represents a specificity of $100 \%$ (Table). In the present study, none of the saliva and liver abscess pus specimens was positive for either $E$. dispar or $E$. moshkovskii by the NM-PCR, which confirms the non-invasive nature of these non-pathogenic species (Table).

The present study, for the first time, demonstrates the release of $E$. histolytica DNA in the saliva specimens of ALA patients by applying NM-PCR.
However, as a diagnostic tool, the limitation of NMPCR was that it could only detect E. histolytica DNA in the saliva specimens of ALA patients who had already received treatment with metronidazole with a sensitivity of only $40 \%$ but could not detect E. histolytica DNA in the saliva specimens of untreated ALA patients. Therefore, the present study on the detection of $E$. histolytica DNA in the saliva of ALA patients may not be used as a diagnostic tool. Nevertheless, the saliva as a clinical specimen offers distinctive advantage over blood as a diagnostic fluid. The first and foremost advantage is that it can be collected non-invasively by individuals with minimum training. Second, the use of saliva as a clinical specimen may prove to be a cost-effective approach for the screening of a large number of patients, especially in epidemiological studies. Finally, saliva has the potential to be used for the diagnosis of invasive infectious diseases because it is collected readily and is also known to contain serum constituents. The serum constituents present in saliva are derived from the salivary gland's local vasculature which ultimately reaches the oral cavity through the flow of gingival fluid (51). However, we feel that additional studies are needed in the field before the true clinical and diagnostic value of saliva as a clinical specimen can be established.

\section{ACKNOWLEDGEMENTS}

The authors thank Dr. C. Graham Clark from the London School of Hygiene \& Tropical Medicine for providing them with lyophilized DNA of standard cultures of E. histolytica HM-1:IMSS, E. dispar SAW760, and E. moshkovskii Laredo. The authors also thank Dr. K.V. Kirubasankar, Department of Preventive and Social Medicine, Jawaharlal Institute of Postgraduate Medical Education and Research, Puducherry, India, for analyzing statistical data.

\section{REFERENCES}

1. Streckfus CF, Bigler LR. Saliva as a diagnostic fluid. Oral Dis 2002;8:69-76.

2. Loeb MB, Riddell RH, James C, Hunt R, Smaill FM. Evaluation of salivary antibodies to detect infection with Helicobacter pylori. Can J Gastroenterol 1997;11:437-40.

3. Schultsz C, Qadri F, Hossain SA, Ahmed F, Ciznar I. Shigella-specific IgA in saliva of children with bacillary dysentery. FEMS Microbiol Immunol 1992;4:65-72.

4. Schwartz BS, Ford DP, Childs JE, Rothman N, Thomas RJ. Anti-tick saliva antibody: a biologic marker of tick exposure that is a risk factor for Lyme disease seropositivity. Am J Epidemiol 1991;134:86-95. 
5. Parry JV, Perry KR, Panday S, Mortimer PP. Diagnosis of hepatitis A and B by testing saliva. J Med Virol 1989;28:255-60.

6. El-Medany OM, El-Din Abdel Wahab KS, Abu Shady EA, Gad El-Hak N. Chronic liver disease and hepatitis $\mathrm{C}$ virus in Egyptian patients. Hepatogastroenterology 1999;46:1895-903.

7. Thieme T, Piacentini S, Davidson S, Steingart K. Determination of measles, mumps, and rubella immunization status using oral fluid samples. JAMA 1994;272:219-21.

8. Jayashree S, Bhan MK, Kumar R, Raj P, Glass R, Bhandari N. Serum and salivary antibodies as indicators of rotavirus infection in neonates. J Infect Dis 1988;158:1117-20.

9. Cuzzubbo AJ, Vaughn DW, Nisalak A, Suntayakorn S, Aaskov J, Devine PL. Detection of specific antibodies in saliva during dengue infection. J Clin Microbiol 1998;36:3737-9.

10. Rice PS, Cohen BJ. A school outbreak of parvovirus B19 infection investigated using salivary antibody assays. Epidemiol Infect 1996;116:331-8.

11. Malamud D. Saliva as a diagnostic fluid. BMJ 1992; 305:207-8.

12. Loyola AM, Durighetto AF, Jr., Silva DA, Jr., Mineo JR. Anti-Toxoplasma gondii immunoglobulins A and G in human saliva and serum. J Oral Pathol Med 1997;26:187-91.

13. Garcia MM, Amorim MN, de Viana Lde G, Katz N, Rabello AL. Detection of anti-Schistosoma antibodies in oral fluids. Mem Inst Oswaldo Cruz 1995;90:513-6.

14. Feldman M, Plancarte A, Sandoval M, Wilson M, Flisser A. Comparison of two assays (EIA and EITB) and two samples (saliva and serum) for the diagnosis of neurocysticercosis. Trans $\mathrm{R}$ Soc Trop Med Hyg 1990;84:559-62.

15. Ramos F, Valenzuela A, Morán P, González E, Ramiro M, Cedillo R et al. Anti-E. histolytica IgA antibodies in saliva of E. histolytica or E. dispar infected individuals: longitudinal study of cohorts. Arch Med Res 1997;28:S327-39.

16. Krook A, Fredlund H, Holmberg H. Diagnosis of pneumococcal pneumonia by detection of antigen in saliva. Eur J Clin Microbiol 1986;5:639-42.

17. Chaita TM, Graham SM, Maxwell SM, Sirivasin W, Sabchareon A, Beeching NJ. Salivary sampling for hepatitis B surface antigen carriage: a sensitive technique suitable for epidemiological studies. Ann Trop Paediatr 1995;15:135-9.

18. Friedman MG. Radioimmunoassay for the detection of virus-specific IgA antibodies in saliva. J Immunol Methods 1982;54:203-11.
19. Perry KR, Brown DW, Parry JV, Panday S, Pipkin C, Richards A. Detection of measles, mumps, and rubella antibodies in saliva using antibody capture radioimmunoassay. J Med Virol 1993;40:235-40.

20. Brown DW, Ramsay ME, Richards AF, Miller E. Salivary diagnosis of measles: a study of notified cases in the United Kingdom, 1991-3. BMJ 1994;308:1015-7.

21. Abd-Alla MD, Jackson TF, Reddy S, Ravdin JI. Diagnosis of invasive amebiasis by enzyme-linked immunosorbent assay of saliva to detect amebic lectin antigen and anti-lectin immunoglobulin G antibodies. J Clin Microbiol 2000;38:2344-7.

22. LaDuca JR, Love JL, Abbott LZ, Dube S, FreidmanKien AE, Poiesz, BJ. Detection of human herpesvirus 8 DNA sequences in tissues and bodily fuids. J Infect Dis 1998;178:1610-5.

23. Miller CS, Berger JR, Mootoor Y, Avdiushko SA, Zhu H, Kryscio RJ. High prevalence of multiple human herpesviruses in saliva from human immunodeficiency virus-infected persons in the era of highly active antiretroviral therapy. J Clin Microbiol 2006;44:2409-15.

24. Pozo F, Tenorio A. Detection and typing of lymphotropic herpesviruses by multiplex polymerase chain reaction. J Virol Methods 1999;79:9-19.

25. Crepin P, Audry L, Rotivel Y, Gacoin A, Caroff C, Bourhy $\mathrm{H}$. Intravitam diagnosis of human rabies by PCR using saliva and cerebrospinal fluid. J Clin Microbiol 1998;36:1117-21.

26. Li C, Musich PR, Ha T, Ferguson DA, Jr., Patel NR, Chi DS et al. High prevalence of Helicobacter pylori in saliva demonstrated by a novel PCR assay. J Clin Pathol 1995;48:662-6.

27. Kasper DL, Braunwald E, Fauci AS, Hauser SL, Longo DL, Jameson JL. Harrison's Principles of internal medicine. $16^{\text {th }}$ ed. New York, NY: McGraw-Hill, 2005:1215-6.

28. Haque R, Mollah NU, Ali IK, Alam K, Eubanks A, Lyerly $\mathrm{D}$ et al. Diagnosis of amebic liver abscess and intestinal infection with the TechLab Entamoeba histolytica II antigen detection and antibody tests. J Clin Microbiol 2000;38:3235-9.

29. Parija SC, Kasinathan S, Rao RS. Rapid indirect haemagglutination (Rapid- IHA) using sensitized chick cells for serodiagnosis of amoebiasis at primary health centre level. J Trop Med Hyg 1989;92:221-6.

30. Parija SC, Kasinathan S, Rao RS. Comparative evaluation of polyxenic and axenic amoebic antigens in indirect haemagglutination (IHA) for serodiagnosis of amoebiasis. Indian J Med Microbiol 1988;6:87-97.

31. Clark CG, Diamond LS. The Laredo strain and other 'Entamoeba histolytica-like' amoebae are Entamoeba moshkovskii. Mol Biochem Parasitol 1991;46:11-8. 
32. Parija SC, Khairnar K. Detection of excretory Entamoeba histolytica DNA in the urine, and detection of $E$. histolytica DNA and lectin antigen in the liver abscess pus for the diagnosis of amoebic liver abscess. BMC Microbiol 2007;7:41.

33. Smoger SH, Mitchell CK, McClave SA. Pyogenic liver abscesses: a comparison of older and younger patients. Age Ageing 1998;27:443-8.

34. Parija SC. Recent trends in the diagnosis of amoebiasis. J Assoc Physicians India 1993;41:383-5.

35. Gandhi BM, Irshad M, Chawla TC, Tandon BN. Enzyme linked protein-A: an ELISA for detection of amoebic antibody. Trans R Soc Trop Med Hyg 1987; 81:183-5.

36. Jackson TF, Gathiram V, Simjee AE. Serological differentiation between past and present infections in hepatic amoebiasis. Trans R Soc Trop Med Hyg 1984; 78:342-5.

37. Yang J, Kennedy MT. Evaluation of enzyme-linked immunosorbent assay for the serodiagnosis of amoebiasis. J Clin Microbiol 1979;10:778-85.

38. Khairnar K, Parija SC, Palaniappan R. Diagnosis of intestinal amoebiasis by using nested polymerase chain reaction-restriction fragment length polymorphism assay. J Gastroenterol 2007;42:631-40.

39. Fotedar R, Stark D, Beebe N, Marriott D, Ellis J, Harkness J. PCR detection of Entamoeba histolytica, Entamoeba dispar, and Entamoeba moshkovskii in stool samples from Sydney, Australia. J Clin Microbiol 2007; 45:1035-7.

40. Lebbad M. Svard SG. PCR differentiation of Entamoeba histolytica and Entamoeba dispar from patients with amoeba infection initially diagnosed by microscopy. Scand J Infect Dis 2005;37:680-5.

41. Roy S, Kabir M, Mondal D, Ali IK, Petri WA, Jr., Haque R. Real-time-PCR assay for diagnosis of Entamoeba histolytica infection. J Clin Microbiol 2005;43:2168-72.

42. Freitas MA, Vianna EN, Martins AS, Silva EF, Pesquero
JL, Gomes MA. A single step duplex PCR to distinguish Entamoeba histolytica from Entamoeba dispar. Parasitology 2004;128:625-8.

43. Khairnar K, Parija SC. A novel nested multiplex polymerase chain reaction (PCR) assay for differential detection of Entamoeba histolytica, E. moshkovskii and E. dispar DNA in stool samples. BMC Microbiol 2007;7:47.

44. Núñez YO, Fernández MA, Torres-Núñez D, Silva JA, Montano I, Maestre JL et al. Multiplex polymerase chain reaction amplification and differentiation of Entamoeba histolytica and Entamoeba dispar DNA from stool samples. Am J Trop Med Hyg 2001;64:293-7.

45. Ali IK, Hossain MB, Roy S, Ayeh-Kumi PF, Petri WA, Haque R et al. Entamoeba moshkovskii infections in children, Bangladesh. Emerg Infect Dis 2003;9:580-4.

46. Parija SC, Khairnar K. Entamoeba moshkovskii and Entamoeba dispar-associated infections in Pondicherry, India. J Health Popul Nutr 2005;23:292-5.

47. Khan U, Mirdha BR, Samantaray JC, Sharma MP. Detection of Entamoeba histolytica using polymerase chain reaction in pus samples from amebic liver abscess. Indian J Gastroenterol 2006;25:55-7.

48. Zengzhu G, Bracha R, Nuchamowitz Y, Cheng-I W, Mirelman D. Analysis by enzyme-linked immunosorbent assay and PCR of human liver abscess aspirates from patients in China for Entamoeba histolytica. J Clin Microbiol 1999;37:3034-6.

49. Zaman S, Khoo J, Ng SW, Ahmed R, Khan MA, Hussain R et al. Direct amplification of Entamoeba histolytica DNA from amoebic liver abscess pus using polymerase chain reaction. Parasitol Res 2000;86:724-8.

50. Crowcroft NS, Vyse A, Brown DWG, Strachan DP. Epidemiology of Epstein-Barr virus infection in preadolescent children: application of a new salivary method in Edinburgh, Scotland. J Epidemiol Community Health 1998;52:101-4.

51. Kaufman E, Lamster IB. The diagnostic applications of saliva—a review. Crit Rev Oral Biol Med 2002;13:197-212. 